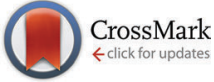

Cite this: Phys. Chem. Chem. Phys., 2016, 18, 1693

Received 20th October 2015, Accepted 8th December 2015

DOI: $10.1039 / \mathrm{c} 5 \mathrm{cp} 06350 \mathrm{~g}$

www.rsc.org/pccp

\title{
1,1,2,2-Tetracyanocyclopropane (TCCP) as supramolecular synthon $\dagger$
}

\author{
Antonio Bauzá, ${ }^{a}$ Antonio Frontera*a and Tiddo J. Mooibroek ${ }^{\star b}$
}

The 1,1,2,2-tetracyanocyclopropane (TCCP) unit presents a synthetically accessible and versatile synthon that can interact with lone-pair or $\pi$-electrons by 'non-covalent carbon bonding'. Complexes of TCCP with common small molecules, anions, aromatics like fullerenes, amino acids and nucleobases were computed at the DFT BP86-D3/def2-TZVP level of theory. Binding energies vary between about $-10 \mathrm{kcal} \mathrm{mol}^{-1}$ for neutral guests and -15 to $-50 \mathrm{kcal} \mathrm{mol}^{-1}$ for anionic species. This is comparable to strong and very strong hydrogen bonding respectively. Thus, in addition to synthons that contain polarized hydrogen or halogen atoms, TCCP presents a new supramolecular synthon that awaits experimental exploitation.

\section{Introduction}

Living matter is for a great part governed by intermolecular recognition phenomena such as substrate/inhibitor/protein binding, ${ }^{1-4}$ signalling events ${ }^{5-8}$ and cell-cell interactions. ${ }^{9-11}$ Intramolecular phenomena such as the folding of proteins ${ }^{12-14}$ or DNA/RNA ${ }^{15-18}$ are governed by the same physical forces. The design and synthesis of molecules that can influence such processes are the basis of many inquiries in supramolecular chemistry, ${ }^{19-23}$ molecular biology ${ }^{24-27}$ and pharmacology. ${ }^{28-30}$ Underpinning the design process is knowing which molecular fragments will engage in favourable intermolecular interactions, i.e. knowing which supramolecular synthons one can use. ${ }^{31-33}$ Prominent among these are synthons that rely on hydrogen bonding or aromatic interactions, such as nucleosides, amino acids and sugars. Chemical modification of such natural synthons is common practice, ${ }^{34-37}$ while artificial supramolecular synthons that rely on other types of intermolecular interactions are rare. Halogen bonding is a noticeable exception, ${ }^{38}$ but in principle Chalcogen, ${ }^{39-41}$ Pnictogen, ${ }^{42-45}$ or Tetrel ${ }^{46-49}$ bonding interactions could similarly be exploited. That these interactions are not yet extensively used in (biochemical) research may in part be due to their novelty. Indeed, these interactions have only been studied in detail in the past decade or so. ${ }^{46,50-55}$ A major obstacle of their exploitation, however, is the synthetic accessibility of identified supramolecular synthons. In particular, the problem is how to incorporate a given synthon in a

\footnotetext{
${ }^{a}$ Department of Chemistry Universitat de les Illes Balears, Crta. de Valldemossa $\mathrm{km} 7.5$, 07122 Palma (Baleares), Spain. E-mail: toni.frontera@uib.es; Fax: +34971 173426

${ }^{b}$ School of Chemistry of the University of Bristol, Cantock's Close, BS8 1TS, Bristol, UK. E-mail: tiddomooibroek@gmail.com

$\dagger$ Electronic supplementary information (ESI) available. See DOI: 10.1039/c5cp06350g
}

larger molecular framework. For example, the sulphur atom in $\mathrm{SO}_{2}$ and $\mathrm{SO}_{3}$ can participate in Chalcogen bonding interactions, ${ }^{56}$ but these entities lack a convenient chemical anchor point.

We have recently highlighted that $\mathrm{sp}^{3}$ hybridized carbon the most abundant tetrel atom in living matter - can be a supramolecular synthon. ${ }^{47,48}$ More specifically, the $1,1,2,2$ tetracyanocyclopropane (TCCP) motif (Scheme 1) was identified as an electron poor bowl, apt to accommodate an electron rich guest. $^{47}$ Two convenient (high yielding) synthetic routes towards this motif are shown in Scheme 1: reaction of a primary or secondary alkyl halide with tetracyanoethylene (top); ${ }^{\text {57-60 }}$ and reaction of an aldehyde or ketone with malonitrile (bottom). ${ }^{61,62}$ In both instances, numerous variations of the R-bearing moieties are readily available and provide a convenient way to obtain a practically infinite amount of TCCP derivatives. Thus, TCCP provides a rather unique case of a synthetically versatile and accessible supramolecular synthon that awaits utilization by the molecular scientists.

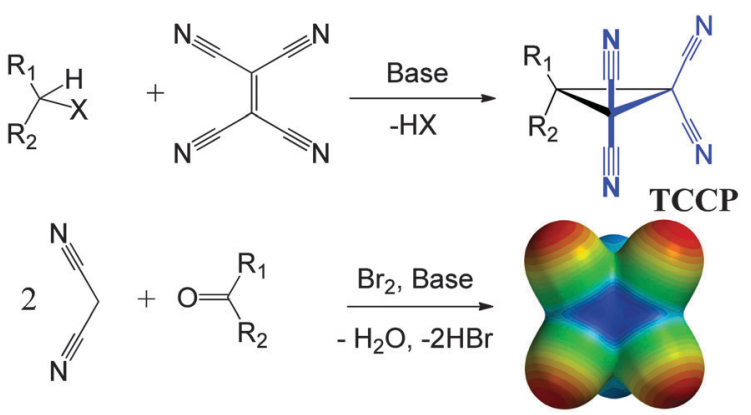

Scheme 1 Synthetic routes to 1,1,2,2-tetracyanocyclopropane (TCCP) structures. The molecular electrostatic potential map of 3,3'-dimethylTCCP was computed at the DFT-B3LYP-6-31G* level of theory and the color code spans from -130 (red) to +150 (blue) kcal mol ${ }^{-1.63}$ 
Anticipating the experimental exploitation of TCCP, we here report on a comprehensive theoretical investigation of the binding interactions of a model for TCCP derivatives (where $\mathrm{R}_{1}=\mathrm{R}_{2}=\mathrm{H}$ ) with three classes of compounds; commonly encountered small (neutral) molecules, common anions, and several aromatic systems including Nature's aromatic building blocks.

\section{Results}

For our enquiries we conducted computations based on density functional theory (DFT) at the BP86-D3/def2-TZVP level of theory and Table 1 summarized the results of the interaction of TCCP with common small molecules. For several of these molecule pairs, $a b$ initio calculations at the MP2/def2-TZVP level of theory were also conducted (denoted 'a' in Table 1) to validate our use of the more economical DFT approach. The comparative results are given in the ESI $\dagger$ (Table S1) and are in excellent agreement: computed distances differ less than

Table 1 Interaction energies $(\Delta E)$, minimum contact distances $(D)$ and densities of bond critical points $(\rho)$ estimated at the DFT BP86-D3/ def2-TZVP level of theory of complexes involving TCCP and several small molecules

\begin{tabular}{|c|c|c|c|c|}
\hline Complex & Guest & $\Delta E\left(\mathrm{kcal} \mathrm{mol}^{-1}\right)$ & $D(\AA)$ & $\rho \cdot 100$ (a.u.) \\
\hline \multicolumn{5}{|l|}{ Control } \\
\hline 1 & $\mathrm{CH}_{4}{ }^{a}$ & -2.3 & $3.167^{a}$ & 0.470 \\
\hline \multicolumn{5}{|c|}{ O-donor atom $(\mathrm{s})$} \\
\hline 2 & $\mathrm{CO}_{2}^{a, c}$ & -3.7 & 2.952 & 0.735 \\
\hline 3 & $\mathrm{H}_{2} \mathrm{O}^{a}$ & -8.5 & 2.819 & 1.094 \\
\hline 4 & $\left(\mathrm{CH}_{3}\right)_{2} \mathrm{O}^{a, b}$ & -10.0 & 2.836 & 1.096 \\
\hline 5 & 1,4-Dioxane ${ }^{b}$ & -11.4 & 2.824 & 1.129 \\
\hline 6 & $\mathrm{THF}^{b}$ & -11.2 & 2.778 & 1.223 \\
\hline 7 & $\left(\mathrm{CH}_{3}\right)_{2} \mathrm{CO}$ & -7.7 & 2.729 & 1.210 \\
\hline 8 & $\mathrm{EtOAc}^{b}$ & -10.8 & 2.752 & 1.190 \\
\hline 9 & Urea & -11.1 & 2.687 & 1.310 \\
\hline 10 & Lactame $^{b}$ & -13.4 & 2.759 & 1.220 \\
\hline 11 & $\left(\mathrm{CH}_{3}\right)_{2} \mathrm{NC}(\mathrm{O}) \mathrm{H}^{b}$ & -15.1 & 2.769 & 1.210 \\
\hline 12 & $\mathrm{CH}_{3} \mathrm{NO}_{2}$ & -7.5 & 3.103 & 0.850 \\
\hline 13 & $\mathrm{H}_{3} \mathrm{PO}^{a}$ & -10.3 & 2.727 & 1.231 \\
\hline 14 & $\left(\mathrm{CH}_{3}\right)_{3} \mathrm{PO}^{a}$ & -14.0 & 2.645 & 1.470 \\
\hline 15 & $\mathrm{H}_{2} \mathrm{SO}^{a}$ & -9.2 & 2.686 & 1.244 \\
\hline 16 & $\left(\mathrm{CH}_{3}\right)_{2} \mathrm{SO}^{a}$ & -12.2 & 2.622 & 1.437 \\
\hline
\end{tabular}

\begin{tabular}{|c|c|c|c|c|}
\hline \multicolumn{5}{|c|}{ Other-donor atoms } \\
\hline 17 & $\mathrm{CO}^{a, c}$ & -3.2 & 3.302 & 0.599 \\
\hline 18 & $\mathrm{~N}_{2}^{a, c}$ & -2.6 & 3.168 & 0.604 \\
\hline 19 & $\mathrm{NH}_{3}{ }^{a}$ & -9.4 & 3.003 & 1.046 \\
\hline 20 & $\mathrm{~N}\left(\mathrm{CH}_{3}\right)_{3}{ }^{a, b}$ & -11.2 & 3.177 & 0.831 \\
\hline 21 & $\mathrm{CH}_{3} \mathrm{CN}$ & -7.3 & 2.962 & 0.963 \\
\hline 22 & Pyridine $^{d}$ & -9.5 & 3.010 & 1.025 \\
\hline 23 & $\mathrm{H}_{2} \mathrm{~S}^{a}$ & -4.5 & 3.400 & 0.654 \\
\hline 24 & $\mathrm{~S}\left(\mathrm{CH}_{3}\right)_{2}{ }^{a}$ & -7.7 & 3.266 & 0.876 \\
\hline 25 & $\mathrm{PH}_{3}{ }^{a}$ & -4.9 & 3.567 & 0.665 \\
\hline 26 & $\mathrm{P}\left(\mathrm{CH}_{3}\right)_{3}{ }^{a}$ & -9.8 & 3.404 & 0.967 \\
\hline 27 & $\mathrm{CH}_{2} \mathrm{Cl}_{2}$ & -4.9 & 3.968 & 0.580 \\
\hline 28 & $\mathrm{CCl}_{4}{ }^{c}$ & -4.2 & 3.686 & 0.558 \\
\hline
\end{tabular}

${ }^{a}$ Complex also computed at the MP2/def2-TZVP level of theory, as detailed in Table S1. ${ }^{b}$ Also XH $\cdots$ NC(TCCP) hydrogen bonding present according to AIM analysis. ${ }^{c}$ Alternate orientation also considered (respectively marked $\mathbf{2}^{\prime} / \mathbf{1 7}^{\prime} / \mathbf{1 8}^{\prime} / \mathbf{2 8}$ in Fig. S1) but found to be less stable. ${ }^{d}$ Another geometry where pyridine interacts with its $\pi$-cloud is less stable at $-7.08 \mathrm{kcal} \mathrm{mol}^{-1}$ (see also complex 54 in Table 3).
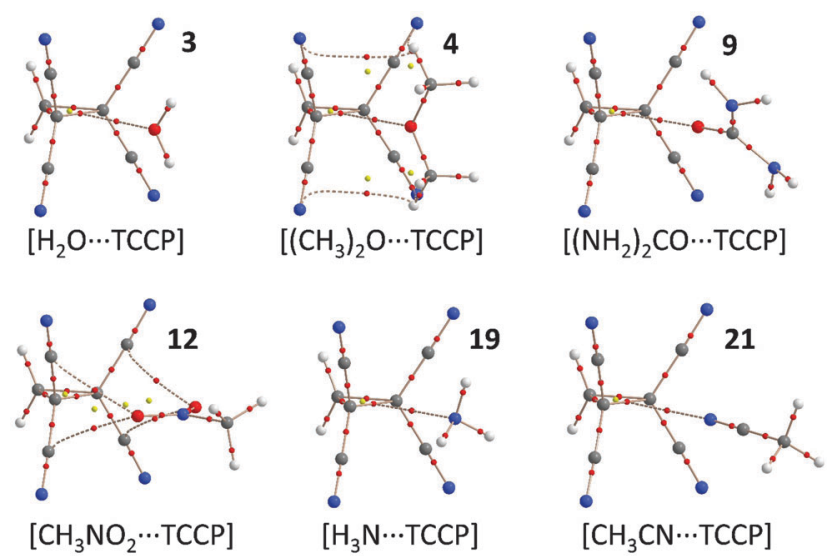

Fig. 1 Molecular geometries of representative complexes of TCCP with small molecules, as computed at the BP86-D3/def2-TZVP level of theory (see also Table 1). The small red dots denote the bond-critical points according to an AIM analysis.

$3 \%$ and computed energies typically less than $10 \%$. In all cases, the minimized complex was subjected to an 'atoms in molecules' (AIM) analysis in order to identify atoms engaging in bonding contacts. ${ }^{64}$ Graphical renderings of these analyses are depicted in Fig. S1 (ESI $\dagger$ ), and Fig. 1 shows representative examples for some complexes with small neutral molecules.

The complexation energy with the control guest methane $\left(-2.3 \mathrm{kcal} \mathrm{mol}^{-1}\right)$ is very small and methane actually is not located in the electron poor binding pocket of TCCP (see Fig. S1, ESI $\dagger$ ). All other guests do engage in tetrel bonding with the $\mathrm{C}_{2}(\mathrm{CN})_{4}$ pocket, although in several structures additional hydrogen bonding with TCCP's N-atom(s) is also observed (i.e. in 4-6, 8, 10, 11, 20). These additional forces might explain the increased stability of these complexes over other, very similar ones. For example, the $\left[\mathrm{H}_{2} \mathrm{O} \cdots \mathrm{TCCP}\right]$ pair 3 has an energy of $-8.45 \mathrm{kcal} \mathrm{mol}^{-1}$, solely due to $\mathrm{O} \cdots \mathrm{C}$ tetrel bonding interactions, while the additional hydrogen bonds with dimethyl ether (4), 1,4dioxane (5) and THF (6) result in energies of about $-11 \mathrm{kcal} \mathrm{mol}^{-1}$. The energies of other small molecules with O-donors (7-16) are very similar, between about -7 and $-10 \mathrm{kcal} \mathrm{mol}^{-1}$. The strongest of these that do not have additional H-bonding according to AIM are trimethylphosphaneoxide $\mathbf{1 4}\left(-14.0 \mathrm{kcal} \mathrm{mol}^{-1}\right)$ and dimethylsulfoxide $16\left(-12.2 \mathrm{kcal} \mathrm{mol}^{-1}\right)$. This is in line with the increased polarization of $\mathrm{O}$ in these molecules.

Other small molecules considered where an atom other than oxygen functions as electron donor (17-28) gave very similar energies, ranging between about -5 to about $-10 \mathrm{kcal} \mathrm{mol}^{-1}$. Carbon monoxide (17) and dinitrogen (18) displayed the lowest predicted energies at about $-3 \mathrm{kcal} \mathrm{mol}^{-1}$.

Interestingly, the series with $\mathrm{H}_{2} \mathrm{O}\left(3 ;-8.5 \mathrm{kcal} \mathrm{mol}^{-1}, 2.82 \AA\right)$ $\mathrm{H}_{2} \mathrm{~S}\left(23 ;-4.5 \mathrm{kcal} \mathrm{mol}^{-1}, 3.40 \AA\right), \mathrm{H}_{3} \mathrm{~N}\left(19 ;-9.4 \mathrm{kcal} \mathrm{mol}^{-1}\right.$, $3.00 \AA)$ and $\mathrm{H}_{3} \mathrm{P}\left(25 ;-4.9 \mathrm{kcal} \mathrm{mol}^{-1}, 3.57 \AA\right)$ suggest that TCCP prefers 'hard' over 'soft' donor atoms, while the trend might also result from the longer distance required by the 'soft' second-row donors.

All anionic guests appears to sit comfortably within the electron poor bowl shape of TCCP, and are held in place solely 

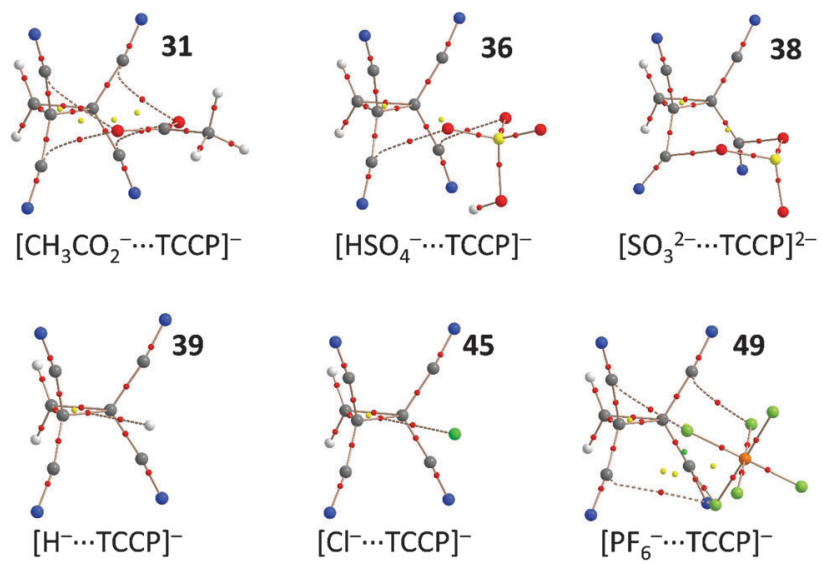

Fig. 2 Molecular geometries of representative complexes of TCCP with anions, as computed at the BP86-D3/def2-TZVP level of theory (see also Table 2). The small red dots denote the bond-critical points according to an AIM analysis.

by one or multiple Tetrel bonding interactions, as evidenced by the AIM analyses (see Fig. 2 for representative examples, but also Fig. S1, ESI $\dagger$ ). The interacting energies are summarized in Table 2, and range typically from $-19.4 \mathrm{kcal} \mathrm{mol}^{-1}$ for $\mathrm{SCN}^{-}$ (43) to $-32.8 \mathrm{kcal} \mathrm{mol}^{-1}$ for acetate (32). The two complexes with the largest energies ( 37 and 38 ) concern dianions $\left(\mathrm{SO}_{4}{ }^{2-}=\right.$ $-68.9 \mathrm{kcal} \mathrm{mol}^{-1} ; \mathrm{SO}_{3}{ }^{2-}=-88.1 \mathrm{kcal} \mathrm{mol}^{-1}$ ). The latter (38) might well have some covalent character; the $\mathrm{C}-\mathrm{C} \equiv \mathrm{N}$ angles $\left(143^{\circ}\right)$ deviate significantly from the $\sim 170-180^{\circ}$ observed in the monoanionic complexes. The $\mathrm{C}-\mathrm{C} \equiv \mathrm{N}$ angles in $\mathbf{3 7}$ are about $164^{\circ}$, indicating that there is much less covalent character.

Table 2 Interaction energies $(\Delta E)$, minimum contact distances $(D)$ and densities of bond critical points $(\rho)$ estimated at the DFT BP86-D3/def2TZVP level of theory of complexes involving TCCP and several anions

\begin{tabular}{|c|c|c|c|c|}
\hline Complex & Guest & $\Delta E\left(\mathrm{kcal} \mathrm{mol}^{-1}\right)$ & $D(\AA)$ & $\rho \cdot 100$ (a.u.) \\
\hline \multicolumn{5}{|c|}{ Anions with O-donor atoms and hydride } \\
\hline 29 & $\mathrm{HO}^{-}$ & -57.7 & 2.286 & 2.850 \\
\hline 30 & $\mathrm{HCO}_{2}{ }^{-}$ & -31.8 & 2.720 & 1.890 \\
\hline 31 & $\mathrm{CH}_{3} \mathrm{CO}_{2}^{-}$ & -32.8 & 2.700 & 1.940 \\
\hline 32 & $\mathrm{HOCO}_{2}^{-}$ & -29.5 & 2.720 & 1.860 \\
\hline 33 & $\mathrm{ClO}_{4}^{-}$ & -18.6 & 2.810 & 1.410 \\
\hline 34 & $\mathrm{NO}_{3}{ }^{-}$ & -26.0 & 2.748 & 1.690 \\
\hline 35 & $\mathrm{H}_{2} \mathrm{PO}_{4}{ }^{-}$ & -29.2 & 2.737 & 1.890 \\
\hline 36 & $\mathrm{HSO}_{4}^{-}$ & -24.1 & 2.764 & 1.740 \\
\hline 37 & $\mathrm{SO}_{4}{ }^{2-}$ & -65.9 & 2.482 & 2.810 \\
\hline 38 & $\mathrm{SO}_{3}{ }^{2-}$ & -88.1 & 2.520 & 7.490 \\
\hline 39 & $\mathrm{H}^{-}$ & -43.4 & 2.409 & 1.680 \\
\hline
\end{tabular}

Anions with $\mathrm{N}$-donor atoms

$\begin{array}{lllll}40 & \mathrm{~N}_{3}{ }^{-} & -26.3 & 2.558 & 1.910 \\ 41 & \mathrm{OCN}^{-} & -25.6 & 2.831 & 2.120 \\ 42 & \mathrm{CN}^{-} & -22.6 & 2.696 & 1.670 \\ 43 & \mathrm{SCN}^{-} & -19.4 & 2.681 & 1.670\end{array}$

Anions with halogen donor atoms
$\begin{array}{lllll}\mathbf{4 4} & \mathrm{F}^{-} & -52.1 & & \\ \mathbf{4 5} & \mathrm{Cl}^{-} & -30.4 & 2.311 & 2.800 \\ \mathbf{4 6} & \mathrm{Br}^{-} & -24.8 & 3.104 & 1.650 \\ \mathbf{4 7} & \mathrm{I}^{-} & -19.6 & 3.369 & 1.160 \\ \mathbf{4 8} & \mathrm{BF}_{4}{ }^{-} & -17.2 & 2.755 & 1.350 \\ \mathbf{4 9} & \mathrm{PF}_{6}{ }^{-} & -14.8 & 2.857 & 1.200\end{array}$

From the series with hydroxide $29\left(-57.7 \mathrm{kcal} \mathrm{mol}^{-1}\right)>$ formate $30 \approx$ acetate $31 \approx$ hydrogen carbonate 32 (about $\left.-30 \mathrm{kcal} \mathrm{mol}^{-1}\right)>$ perchlorate $33\left(-18.6 \mathrm{kcal} \mathrm{mol}^{-1}\right)$ it seems evident that the interacting energies decrease when the negative charge becomes more spread out over a larger anion (although the hydride result (39) breaks this trend, likely due to the short distance). The anions where a $\mathrm{N}$-donor atom formally bears the negative charge (40-43) bind weaker (about -20-25 kcal $\mathrm{mol}^{-1}$ ) than the small anions with O-donor atoms (e.g. formate 30 with $-31.8 \mathrm{kcal} \mathrm{mol}^{-1}$ ). In the series with halogen donor atoms (44-49) there is a clear trend with energies ranging from $-52.1 \mathrm{kcal} \mathrm{mol}^{-1}$ for $\mathrm{F}^{-}(\mathbf{4 4})$ to $-14.8 \mathrm{kcal} \mathrm{mol}^{-1}$ for $\mathrm{PF}_{6}{ }^{-}$(49).

In general the interaction energies reported in Tables 1 and 2 are in good agreement with the MEP values of the guest molecules on their negative regions. For instance in the neutral $\mathrm{O} / \mathrm{N}$ Lewis bases the MEP values vary from $-58 \mathrm{kcal} \mathrm{mol}^{-1}$ [for $\left.\left(\mathrm{CH}_{3}\right)_{3} \mathrm{PO}\right]$ to $-12 \mathrm{kcal} \mathrm{mol}^{-1}$ (for $\mathrm{N}_{2}$ ). Moreover, for the monoanionic guests, the MEP values vary from $-216 \mathrm{kcal} \mathrm{mol}^{-1}$ $\left(\mathrm{F}^{-}\right)$to $-125 \mathrm{kcal} \mathrm{mol}^{-1}\left(\mathrm{PF}_{6}{ }^{-}\right)$, in line with the interaction energies observed for their corresponding complexes. The $\mathrm{SO}_{3}{ }^{2-}$ dianionic guest exhibits the most negative MEP value $\left(-247 \mathrm{kcal} \mathrm{mol}^{-1}\right)$ and the largest interaction energy (see Table 2).

As it appears from the data collected in Table 3, small isolated $\pi$-systems like ethene (50) and ethyne (51) bind to TCCP with about $-5 \mathrm{kcal} \mathrm{mol}^{-1}$. Small conjugated systems such as benzene (53) bind even stronger (about $-7 \mathrm{kcal} \mathrm{mol}^{-1}$ ), while larger condensed hydrocarbons (55-60) such as pyrene (58) bind stronger still (about $-10 \mathrm{kcal} \mathrm{mol}^{-1}$ ). As is apparent from the AIM analyses shown in Fig. 3, all these complexes are held together mainly by tetrel bonding interactions (in some cases perhaps stabilized by weak $\mathrm{CN} \cdots \mathrm{HC}$ polar contacts).

It is interesting to note that the binding energy peaks at coronene $\left(60 ;-12.6 \mathrm{kcal} \mathrm{mol}^{-1}\right)$, which can be seen as a model for graphene. Likewise, the binding energies calculated with several fullerenes (61-64) are substantial and strongest for a model of carbon nanotube $(12,0)$ at $-12.6 \mathrm{kcal} \mathrm{mol}^{-1}(\mathbf{6 4})$.

Also noteworthy is the positioning of TCCP over pyrene in $\mathbf{5 8}$ and triphenylene in 59; apparently TCCP prefers the periphery over the center. It is known what $\mathrm{Li}^{+}$also preferentially binds to a peripheral ring in large condensed hydrocarbons. ${ }^{65}$ However, in 60 the TCCP sits perfectly above the center of the coronene.

Encouraged by the energies computed with small molecules and aromatic systems, we expected that Nature's aromatic building blocks could bind to TCCP as well. The computational verifications of this expectation are listed in Table 3 as complexes 65-73 and Fig. 4 shows the molecular structure and AIM analysis of several representative examples. Models of tyrosine $65\left(-8.1 \mathrm{kcal} \mathrm{mol}^{-1}\right)$ and tryptophan $66\left(-11.7 \mathrm{kcal} \mathrm{mol}^{-1}\right)$ interact much like condensed hydrocarbons, binding to TCCP with their $\pi$-electrons. Histidine $67\left(-11.6 \mathrm{kcal} \mathrm{mol}^{-1}\right)$ seems to prefer binding to TCCP with its $\mathrm{N}$-atom. When protonated, histidine moves away from TCCP's electron poor binding pocket and instead establishes a strong hydrogen bond with one of the N-atoms in TCCP. The binding energies computed with the nucleobases (69-73) are very similar at 
Table 3 Interaction energies $(\Delta E)$, minimum contact distances $(D)$ and densities of bond critical points $(\rho)$ estimated at the DFT BP86-D3/def2TZVP level of theory of complexes involving TCCP and several $\pi$-systems

\begin{tabular}{lllll}
\hline Complex & Guest & $\Delta E\left(\mathrm{kcal} \mathrm{mol}^{-1}\right)$ & $D(\AA)$ & $\rho \cdot 100$ (a.u.) \\
\hline
\end{tabular}

Simple isolated $\pi$-systems (control)

$\begin{array}{llrrr}\mathbf{5 0} & \text { Ethene } & -5.6 & 3.458 & 0.531 \\ \mathbf{5 1} & \text { Ethyne } & -4.3 & 3.431 & 0.528\end{array}$

Simple extended $\pi$-systems

$\begin{array}{lllll}\mathbf{5 2} & \text { Cyclobutadiene } & -6.9 & 3.502 & 0.660 \\ \mathbf{5 3} & \text { Benzene }_{\mathbf{5 4}} & -8.5 & 3.601 & 0.649 \\ & \text { Pyridine }^{a} & -7.1 & 3.697 & 0.629\end{array}$

Larger extended $\pi$-systems

$\begin{array}{llrll}\mathbf{5 5} & \text { Naphtalene } & -8.5 & 3.800 & 0.222 \\ \mathbf{5 6} & \text { Antracene } & -10.1 & 3.727 & 0.585 \\ \mathbf{5 7} & \text { Phenanthrene } & -11.4 & 3.600 & 0.527 \\ \mathbf{5 8} & \text { Pyrene } & -11.9 & 3.581 & 0.710 \\ \mathbf{5 9} & \text { Triphenylene } & -11.8 & 3.665 & 0.657 \\ \mathbf{6 0} & \text { Coronene } & -12.6 & 3.698 & 0.692\end{array}$

Fullerenes

$\begin{array}{llrrr}\mathbf{6 1} & \text { C60 } & -7.7 & 3.762 & 0.672 \\ \mathbf{6 2} & \text { CNT }(8,0) & -11.6 & 3.545 & 0.723 \\ \mathbf{6 3} & \text { CNT }(10,0) & -12.3 & 3.540 & 0.710 \\ \mathbf{6 4} & \text { CNT }(12,0) & -12.7 & 3.549 & 0.686\end{array}$

Nature's aromatic building bocks

$\begin{array}{llrll}\text { 65 } & \text { Model of Tyr } & -8.1 & 3.650 & 0.671 \\ 66 & \text { Model of Trp }^{b} & -11.7 & 3.627 & 0.693 \\ 67 & \text { Model of His }^{b} & -11.6 & 2.928 & 1.159 \\ \mathbf{6 8} & \text { Model of His }^{+b} & -17.6 & 1.841^{a} & 3.500 \\ \mathbf{6 9} & \text { Adenine } & -11.2 & 3.710 & 0.643 \\ 70 & \text { Guanine }_{71} & -11.3 & 3.228 & 0.598 \\ 71 & \text { Thymine }^{b} & -11.5 & 2.767 & 1.217 \\ 72 & \text { Cytosine }^{b} & -14.4 & 2.925 & 1.432 \\ 73 & \text { Uracil }^{b} & -10.6 & 2.787 & 1.160\end{array}$

${ }^{a}$ Another geometry where pyridine interacts with its $\mathrm{N}$-atom is more stable at $-9.5 \mathrm{kcal} \mathrm{mol}^{-1}$ (see also complex 22 Table 1 ). ${ }^{b}$ No interaction with the $\pi$-system.

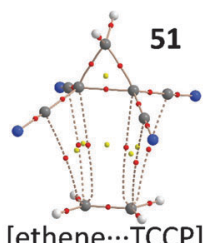

[ethene...TCCP]

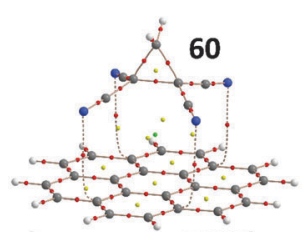

[coronene...TCCP]

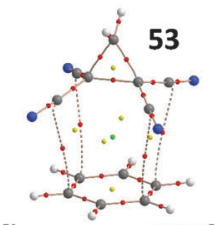

[benzene...TCCP]

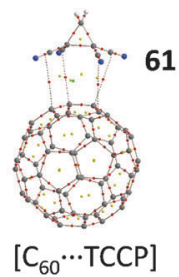

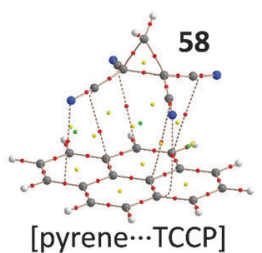

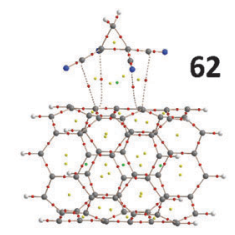

[CNT $(8,0) \cdots$ TCCP]
Fig. 3 Molecular geometries of representative complexes of TCCP with $\pi$-systems, as computed at the BP86-D3/def2-TZVP level of theory (see also Table 3). The small red dots denote the bond-critical points according to an AIM analysis.

about $-11 \mathrm{kcal} \mathrm{mol}^{-1}$. Adenine (69) and guanine (70) bind with their $\pi$-surfaces, while the thymine (71), cytosine (72) and uracil (73) interact with their lone-pair electrons on $\mathrm{O}$ and/or $\mathrm{N}$ and additional hydrogen bonding.

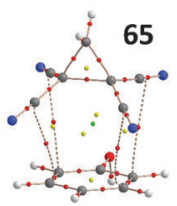

[tyrosine $\cdots \mathrm{TCCP}$ ]

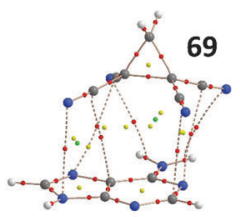

[adenine $\cdots$ TCCP]

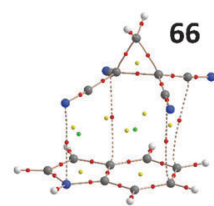

[tryptophan $\cdots$ TCCP]

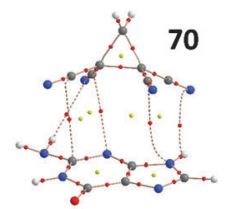

[guanine $\cdots$ TCCP]
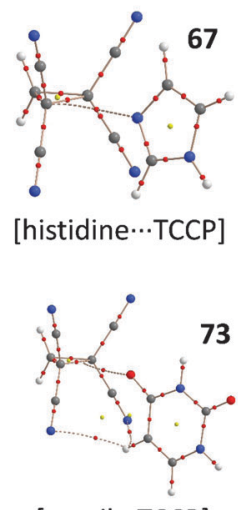

[uracil $\cdots$ TCCP]
Fig. 4 Molecular geometries of complexes of TCCP with some of Nature's aromatic building blocks, as computed at the BP86-D3/def2-TZVP level of theory (see also Table 3). The small red dots denote the bond-critical points according to an AIM analysis.

Next, we wondered how a host molecule with several appropriately-spaced TCCP units would interact with some size-complementary electron rich guests. To this end we conjured one bipodal and two tripodal claw-like hosts (Fig. S2, ESI $\dagger$ ) in which the linking unit assures an appropriate space in between TCCP-moieties and also allows for the correct angles so that the $\mathrm{C}_{2}(\mathrm{CN})_{4}$ 'binding pockets' can face each other. We computed interacting energies with a selection of guests (see Table 4). The molecular geometries of selected complexes are shown in Fig. 5 (the whole series is shown in Fig. S3, ESI†). AIM analyses were also performed and revealed tetrel bonding in all cases (not shown due to congested graphics).

The bipodal host interacts with some neutral and 'flat' molecules with about -5 to $-10 \mathrm{kcal} \mathrm{mol}^{-1}$ (74-77); while the interaction of the spherical halide anions is much larger

Table 4 Interaction energies $(\Delta E)$ and minimum contact distances $(D)$ estimated at the DFT BP86-D3/def2-TZVP level of theory of complexes involving host molecules with multiple TCCP-units

\begin{tabular}{llcl}
\hline Complex & Guest & $\Delta E^{a}\left(\mathrm{kcal} \mathrm{mol}^{-1}\right)$ & $D(\AA)$ \\
\hline Bipodal host & & & \\
$\mathbf{7 4}$ & $\mathrm{H} \mathrm{O}^{\mathrm{O}}$ & -5.6 & 3.226 \\
$\mathbf{7 5}$ & $\mathrm{H} \mathbf{S}^{\mathrm{S}}$ & -5.7 & 3.466 \\
$\mathbf{7 6}$ & Benzene & -12.4 & 3.622 \\
$\mathbf{7 7}$ & Pyridine & -9.6 & 3.634 \\
$\mathbf{7 8}$ & $\mathrm{F}^{-}$ & -67.1 & 2.489 \\
$\mathbf{7 9}$ & $\mathrm{Cl}^{-}$ & -41.3 & 3.005 \\
$\mathbf{8 0}$ & $\mathrm{Br}^{-}$ & -34.1 & 3.177 \\
$\mathbf{8 1}$ & $\mathrm{I}^{-}$ & -27.0 & 3.411 \\
& & & \\
Tripodal hosts & & & 3.403 \\
$\mathbf{8 2}$ & $\mathrm{BF}_{4}{ }^{-}$ & -27.5 & 3.403 \\
$\mathbf{8 3}$ & $\mathrm{ClO}_{4}{ }^{-}$ & -31.5 & 2.718 \\
$\mathbf{8 4}$ & $\mathrm{NO}_{3}{ }^{-}$ & -41.1 & 3.381 \\
$\mathbf{8 5}$ & $\mathrm{BF}_{4}{ }^{-}$ & -23.4 & 2.811 \\
$\mathbf{8 6}$ & $\mathrm{ClO}_{4}{ }^{-}$ & -22.2 & 2.649 \\
$\mathbf{8 7}$ & $\mathrm{NO}_{3}$ & -22.9 &
\end{tabular}

${ }^{a}$ Energies relative to unbound hosts in its energy minimal conformer (as estimated by a Monte Carlo MMFF simulation prior to the DFT minimum energy calculation). For geometries see Fig. S2 (compounds 88-90). 


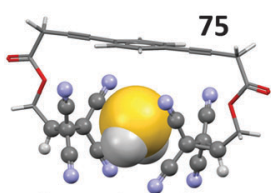

$\left[\mathrm{H}_{2} \mathrm{~S} \cdots\right.$ bipod]

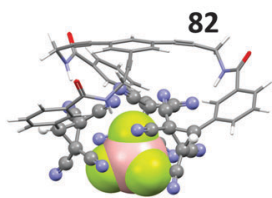

$\left[\mathrm{BF}_{4}^{-} \text {-..tripod 1] }\right]^{-}$

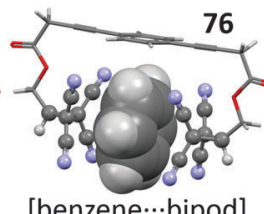

[benzene $\cdots$ bipod]
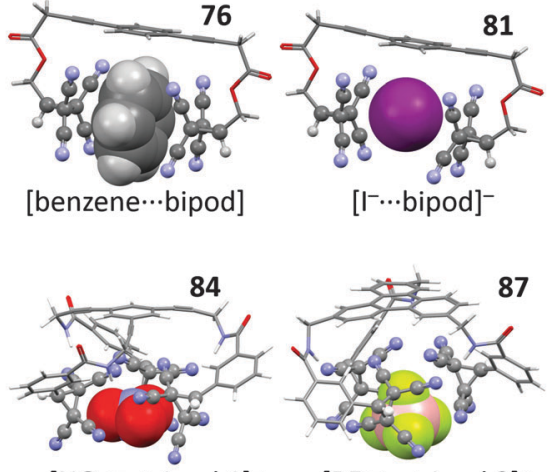

$\left[\mathrm{NO}_{3}{ }^{-} \cdots \text { tripod } 1\right]^{-}$

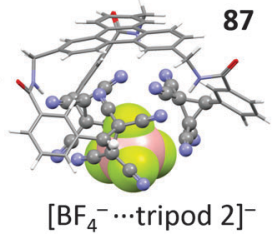

$\left[\mathrm{BF}_{4}^{-}\right.$-..tripod 2]-
Fig. 5 Molecular geometries of complexes of bipodal (top) and tripodal (bottom) TCCP-hosts with some electron rich guests, as computed at the BP86-D3/def2-TZVP level of theory (see also Table 4).

varying between -30 and $-70 \mathrm{kcal} \mathrm{mol}^{-1}$ (78-81). The two tripodal hosts seem to complement the tetrahedral anions $\mathrm{BF}_{4}{ }^{-}$ $(82,85), \mathrm{ClO}_{4}{ }^{-}(83,86)$ as well as the trigonal planar $\mathrm{NO}_{3}{ }^{-}$ $(84,87)$ with interacting energies of about -20 to $-40 \mathrm{kcal} \mathrm{mol}^{-1}$.

These energies are generally larger compared to the analogous interaction with a single TCCP unit (Tables 2 and 3). For example, $78\left(-67.1 \mathrm{kcal} \mathrm{mol}^{-1}\right)$ is about $30 \%$ more stable than 44 $\left(-52.08 \mathrm{kcal} \mathrm{mol}^{-1}\right)$ and $82\left(-27.5 \mathrm{kcal} \mathrm{mol}^{-1}\right)$ is about $60 \%$ more stable than $48\left(-17.17 \mathrm{kcal} \mathrm{mol}^{-1}\right)$. That the stabilization is not strictly additive is likely a result of some repulsive interactions in the complex (e.g. $\mathrm{CN} \cdots \mathrm{NC}$ ), some strain on the conformation of the host (e.g. the $\mathrm{Ar}-\mathrm{C} \equiv \mathrm{C}-\mathrm{CH}_{2}$ units in $\mathbf{8 2}$ and $\mathbf{8 4}$ are not perfectly linear), and/or the decreased electronegativity of the guest upon binding to one TCCP moiety.

\section{Discussion and conclusions}

From the above results it is clear that TCCP derivatives can accommodate a plethora of guest molecules that bear lone-pair electrons, $\pi$-electrons and/or a negative charge. The main mode of interaction with these electron rich entities is tetrel bonding with TCCP's electron deficient $\mathrm{C}_{2}(\mathrm{CN})_{4}$ bowl. Hydrogen bonding with the cyano $\mathrm{N}$-atoms may further stabilize the complex (e.g. complex 6 with THF).

The binding energies of about $-10 \mathrm{kcal} \mathrm{mol}^{-1}$ observed with various neutral guest molecules are comparable in strength to strong hydrogen bonding involving charge-neutral H-bonding pairs. ${ }^{66}$ The values of about -15 to $-30 \mathrm{kcal} \mathrm{mol}^{-1}$ - typically observed with various anions - is truly remarkable because they are comparable in strength to very strong (ionic) hydrogen bonding. ${ }^{66}$ The exceptionally large enthalpies computed for $\mathrm{H}^{-}\left(-43.4 \mathrm{kcal} \mathrm{mol}^{-1}\right) \mathrm{HO}^{-}\left(-57.7 \mathrm{kcal} \mathrm{mol}^{-1}\right)$ and $\mathrm{F}^{-}$ $\left(-52.1 \mathrm{kcal} \mathrm{mol}^{-1}\right)$ even far exceed the common benchmark for strong hydrogen bonding (about $-35 \mathrm{kcal} \mathrm{mol}^{-1}$ ). ${ }^{66}$

The large energies of formation computed between TCCP and (models of) fullerenes (about $-10 \mathrm{kcal} \mathrm{mol}^{-1}$ ) was somewhat expected, as TCCP's bowl-like shape and electron positive core are complementary to the concave shape and electron rich surface of fullerenes. This complementarity hints towards the potential of TCCP derivatives to act as facial amphiphiles to help mobilize these carbon isomorphs in solution. ${ }^{67-70}$ Other charge-neutral supramolecular approaches for binding fullerenes indeed seem far less apt. For example, typical binding energies of hydrogen- $\pi$ and halogen- $\pi$ interactions are estimated at about $1-5 \mathrm{kcal} \mathrm{mol}^{-1},{ }^{1,72}$ while not being shape-complementary to fullerenes at all.

Perhaps the most important result is the difference in geometric preferences of TCCP binding to (models of) amino acids and nucleobases. This implies that TCCP derivatives might selectively nest themselves in proteins and DNA/RNAtype molecules. In this context it is worth mentioning that TCCP derivatives are expected to be poorly hydrated in aqueous solution (no strong $\mathrm{H}$-bond donors) and thus also interact with biomolecules by virtue of the hydrophobic effect. The potential of TCCP derivatives to bind strongly and selectively to biomolecules implies that TCCP might be engineered to influence the functioning of biomachineries, which in turn might have pharmacological implications. Additionally, the bipodal and tripodal TCCP hosts illustrate that strategically placed TCCP-units may greatly enhance the affinity for a guest molecule, just like multiple $\mathrm{H}$-bond donors within a protein can result in high affinity binding to a ligand.

In summary we highlighted that TCCP is an accessible supramolecular synthon that acts as an 'electron sponge', mainly by virtue of tetrel bonding interactions. Its unique bowl-like shape, electron deficient core, and (presumed) hydrophobic character make TCCP-derivatives a promising new addition to the (bio)chemists toolbox (e.g. the PDB is void of TCCP-like ligands). As a result, following this theoretical exploration we anticipate that experimental exploitation of this unit will soon unveil its functional potential.

\section{Acknowledgements}

A. B. and A. F. thank DGICYT of Spain (projects CTQ201457393-C2-1-P and CONSOLIDER INGENIO CSD2010-00065, FEDER funds) for funding.

\section{References}

1 S. Jones and J. M. Thornton, Proc. Natl. Acad. Sci. U. S. A., 1996, 93, 13 .

2 L. Lo Conte, C. Chothia and J. Janin, J. Mol. Biol., 1999, 285, 2177.

3 D. D. Boehr, R. Nussinov and P. E. Wright, Nat. Chem. Biol., 2009, 5, 789.

4 C. R. Bertozzi and L. L. Kiessling, Science, 2001, 291, 2357.

5 B. Baker, P. Zambryski, B. Staskawicz and S. P. DineshKumar, Science, 1997, 276, 726.

6 S. Akira, K. Takeda and T. Kaisho, Nat. Immunol., 2001, 2, 675.

7 W. Strober, P. J. Murray, A. Kitani and T. Watanabe, Nat. Rev. Immunol., 2006, 6, 9.

8 E. Meylan, J. Tschopp and M. Karin, Nature, 2006, 442, 39.

9 E. Ruoslahti and M. D. Pierschbacher, Science, 1987, 238, 491. 
10 C. Kasper, H. Rasmussen, J. S. Kastrup, S. Ikemizu, E. Y. Jones, V. Berezin, E. Bock and I. K. Larsen, Nat. Struct. Biol., 2000, 7, 389.

11 E. H. Chen and E. N. Olson, Science, 2005, 308, 369.

12 M. J. Gething and J. Sambrook, Nature, 1992, 355, 33.

13 A. Sali, E. Shakhnovich and M. Karplus, Nature, 1994, 369, 248. 14 C. M. Dobson, Nature, 2003, 426, 884.

15 A. H. J. Wang, G. J. Quigley, F. J. Kolpak, J. L. Crawford, J. H. van Boom, G. van der Marel and A. Rich, Nature, 1979, 282, 680 .

16 B. N. Conner, T. Takano, S. Tanaka, K. Itakura and R. E. Dickerson, Nature, 1982, 295, 294.

17 A. H. J. Wang, S. Fujii, J. H. van Boom, G. A. van der Marel, S. A. A. van Boeckel and A. Rich, Nature, 1982, 299, 601.

18 M. C. Nagan, S. S. Kerimo, K. Musier-Forsyth and C. J. Cramer, J. Am. Chem. Soc., 1999, 121, 7310.

19 J. M. Lehn, Angew. Chem., Int. Ed., 1990, 29, 1304.

20 J. F. Stoddart, Chem. Soc. Rev., 1979, 8, 85.

21 A. P. Davis and R. S. Wareham, Angew. Chem., Int. Ed., 1999, 38, 2978.

22 J. H. van Maarseveen, J. N. H. Reek and J. W. Back, Angew. Chem., Int. Ed., 2006, 45, 1841.

23 T. J. Mooibroek, J. M. Casas-Solvas, R. L. Harniman, C. M. Renney, T. S. Carter, M. P. Crump and A. P. Davis, Nat. Chem., 2015, DOI: 10.1038/nchem.239.

24 J. W. Trauger, E. E. Baird and P. B. Dervan, Nature, 1996, 382, 559.

25 K. Ding, Y. Lu, Z. Nikolovska-Coleska, S. Qiu, Y. S. Ding, W. Gao, J. Stuckey, K. Krajewski, P. P. Roller, Y. Tomita, D. A. Parrish, J. R. Deschamps and S. M. Wang, J. Am. Chem. Soc., 2005, 127, 10130.

26 C. C. Lee, J. A. MacKay, J. M. J. Frechet and F. C. Szoka, Nat. Biotechnol., 2005, 23, 1517.

27 U. T. Bornscheuer, G. W. Huisman, R. J. Kazlauskas, S. Lutz, J. C. Moore and K. Robins, Nature, 2012, 485, 185.

28 I. D. Kuntz, Science, 1992, 257, 1078.

29 S. L. Schreiber, Science, 2000, 287, 1964.

30 M. D. Burke and S. L. Schreiber, Angew. Chem., Int. Ed., 2004, 43, 46.

31 V. R. Thalladi, B. S. Goud, V. J. Hoy, F. H. Allen, J. A. K. Howard and G. R. Desiraju, Chem. Commun., 1996, 401.

32 A. Nangia and G. R. Desiraju, Top. Curr. Chem., 1998, 198, 57.

33 G. R. Desiraju, Angew. Chem., Int. Ed., 2007, 46, 8342.

34 SPR - Carbohydrate Chemistry, RSC Publishing, Cambridge (UK), 1968-present.

35 Amino Acids, Peptides and Proteins in Organic Chemistry, ed. A. B. Hughes, Wiley-VCH, Weinheim, 2009, vol. 2.

36 Recent Advances in Nucleosides_Chemistry and Chemotherapy, ed. C. K. Chu, Elsevier Science, Amsterdam (NL), 2002.

37 Chemical Synthetic Biology, ed. P. L. Luisi and C. Chiarabelli, John Wiley \& Sons, Chichester (UK), 2011.

38 P. Metrangolo, H. Neukirch, T. Pilati and G. Resnati, Acc. Chem. Res., 2005, 38, 386.

39 M. Iwaoka, S. Takemoto and S. Tomoda, J. Am. Chem. Soc., 2002, 124, 10613.

40 P. Sanz, O. Mó and M. Yáñez, Phys. Chem. Chem. Phys., 2003, 5, 2942.
41 D. B. Werz, R. Gleiter and F. Rominger, J. Am. Chem. Soc., 2002, 124, 10638.

42 S. Zahn, R. Frank, E. Hey-Hawkins and B. Kirchner, Chem. Eur. J., 2011, 17, 6034.

43 P. Kilian, A. M. Z. Slawin and J. D. Woollins, Chem. - Eur. J., 2003, 9, 215.

44 S. Scheiner, J. Chem. Phys., 2011, 134, 094315.

45 J. E. Del Bene, I. Alkorta, G. Sanchez-Sanz and J. Elguero, J. Phys. Chem. A, 2012, 116, 9205.

46 A. Bauza, T. J. Mooibroek and A. Frontera, Angew. Chem., Int. Ed., 2013, 52, 12317.

47 A. Bauza, T. J. Mooibroek and A. Frontera, Chem. - Eur. J., 2014, 20, 10245.

48 A. Bauza, T. J. Mooibroek and A. Frontera, Chem. Commun., 2014, 50, 12626.

49 S. J. Grabowski, Phys. Chem. Chem. Phys., 2014, 16, 1824.

50 P. Politzer, K. E. Riley, F. A. Bulat and J. S. Murray, Comput. Theor. Chem., 2012, 998, 2.

51 P. Politzer, J. S. Murray and T. Clark, Phys. Chem. Chem. Phys., 2013, 15, 11178.

52 J. S. Murray, P. Lane, T. Clark and P. Politzer, J. Mol. Model., 2007, 13, 1033.

53 J. S. Murray, P. Lane and P. Politzer, Int. J. Quantum Chem., 2007, 107, 2286.

54 J. S. Murray, P. Lane and P. Politzer, J. Mol. Model., 2009, 15, 723.

55 J. S. Murray, K. E. Riley, P. Politzer and T. Clark, Aust. J. Chem., 2010, 63, 1598.

56 L. M. Azofra, I. Alkorta and S. Scheiner, Theor. Chem. Acc., 2014, 133, 1586.

57 K. Kayukova and N. Nikolaev, Russ. J. Org. Chem., 2004, 40, 1382.

58 O. E. Nasakin, P. M. Lukin and A. V. Sadovoi, Russ. J. Org. Chem., 1993, 29, 1598.

59 E. Sheverdov, S. Nasakin and K. Chernushkin, Russ. J. Org. Chem., 2000, 70, 1251.

60 J.-Y. Lee and H. K. Hall, J. Org. Chem., 1990, 55, 4963.

61 M. N. Elinson, A. N. Vereshchagin, N. O. Stepanov, A. I. Ilovaisky, A. Y. Vorontsov and G. I. Nikishin, Tetrahedron, 2009, 65, 6057.

62 N. Noroozi Pesyan, M. A. Kimia, M. Jalilzadeh and E. Sahin, J. Chin. Chem. Soc., 2013, 60, 35.

63 J. S. Murray and P. Politzer, Comput. Mol. Biosci., 2011, 1, 153. 64 R. F. W. Bader, Acc. Chem. Res., 1985, 18, 9.

65 J. F. Gal, P. C. Maria, M. Decouzon, O. Mó, M. Yáñez and J. L. M. Abboud, J. Am. Chem. Soc., 2003, 125, 10394.

66 T. Steiner, Angew. Chem., Int. Ed., 2002, 41, 48.

67 X. Li, X. Wang, L. Zhang, S. Lee and H. Dai, Science, 2008, 319, 1229.

68 D. Tasis, N. Tagmatarchis, A. Bianco and M. Prato, Chem. Rev., 2006, 106, 1105.

69 D. A. Britz and A. N. Khlobystov, Chem. Soc. Rev., 2006, 35, 637.

70 D. M. Guldi, F. Zerbetto, V. Georgakilas and M. Prato, Acc. Chem. Res., 2005, 38, 38.

71 A. Forni, S. Pieraccini, S. Rendine and M. Sironi, J. Comput. Chem., 2014, 35, 386.

72 L. M. Salonen, M. Ellermann and F. Diederich, Angew. Chem., Int. Ed., 2011, 50, 4808. 